\title{
Educational Policies and Curriculum in Mexican Scenarios
}

\author{
David As ael Gutié rre z Hernánde $z^{1, *}$, Yazpik Hernández $\operatorname{Vargas}^{2}$, Flavio Mance ra Olivares ${ }^{2}$, \\ Mauricio Salvatori Morales ${ }^{1}$
}

\begin{abstract}
${ }^{1}$ Escuela de Ingenierías. Universidad De La Salle Bajío. Av. Universidad 602, Col. Lomas del Campestre, León, Gto. México ${ }^{2}$ Unidad Profesional Interdisciplinaria de Ingeniería campus Guanajuato. Instituto Politécnico Nacional. Silao, Guanajuato, México
\end{abstract}

\begin{abstract}
Educational Polic ies have visualized the need of curriculum adaptation starting from basic education up to the university, according to the requirements of a globalized society; nevertheless educational polic ies should point not only to teachers' specific classroom tasks, but also towards congruence amongst high rank government positions, mid management and professors who are in charge of carrying out those policies in the day by day school scenarios. This paper pretends to display the gaps that some educational policies have left over and which have an impact in the learning performance of alumni in different educational levels.
\end{abstract}

Keywords Educational Policy, Higher Education, Curriculum, Curricular Design, University Curricula

\section{Introduction}

Mexican Education and its policies has taken an important role not only in the legislative agenda, but also in forums, debates, academic researches and other spaces; nevertheless, one constant need within laws, rules and regulation for education is innovation for curriculum.

On one hand Innovation can be tight either to pedagogy, management or Information and Communication Technologies (ICTs), but not always seen as a systemic mu lti disciplinarian integrator. On the other hand Curriculum seems to be only, the number of credits and or subjects that an individual must consider in order to become what the school has projected.

The term holistic education is mentioned several times within publications of curricular analysis, nonetheless best practices as well as deeper analys is have been far from real. Holistic education and curriculum is seen in th is article as a three axes object (figure 1) in which advancements can no longer stop in isolated attempts but integrated achievements instead.

As the institutions get acquainted with what goes wrong it usually starts a linear process, let us exemplify with three different scenarios.

Scenario 1. Due to the local results shown by the Program for International Student Assessment (PISA), a scholar institution realizes that there is a poor learning performance,

* Corresponding author:

dgutierrez@cboaa.com (David Asael Gutiérrez Hernández)

Published online at http://journal.sapub.org/edu

Copyright (C) 2012 Scientific \& Academic Publishing. All Rights Reserved so it is decided that academic personnel gets trained in competencies approach (Figure 2). Through pedagogical means it is expected to get higher results in the midterm.

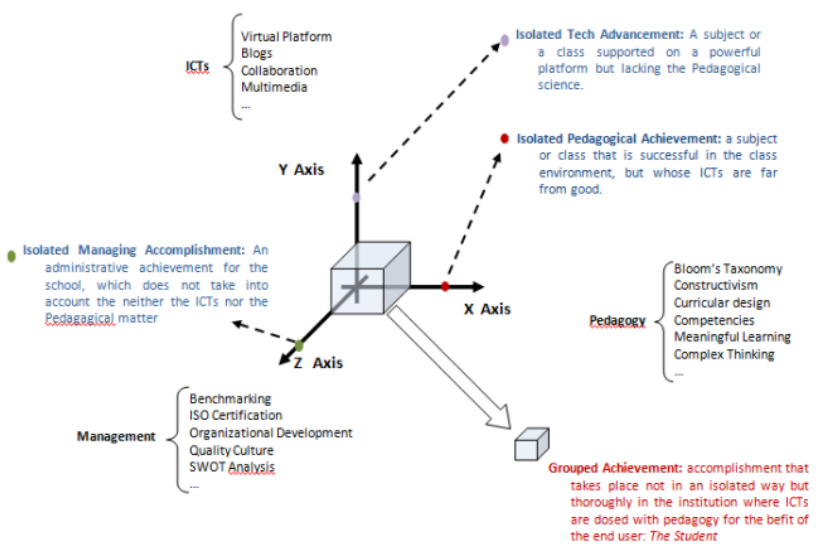

Figure 1. Holistic Education

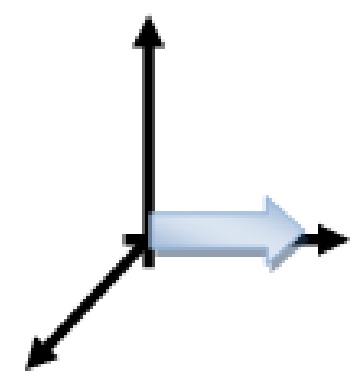

Figure 2. The pedagogy Axis Only

Scenario 2. Authorities at a local school have noticed that end users are no longer encouraged to enroll therein, because throughout the community it is being said that other similar 
schools are using computers more often and students there seem to be happier. In this scenario school authorities decide to use up the allocated budget for the purchase of cutting edge white boards, computer projectors and other items. Without having trained academic staff, the school expectation is that these new technological resources get to be the solution for Customer Sat is faction (CSAT), see Figure 3.

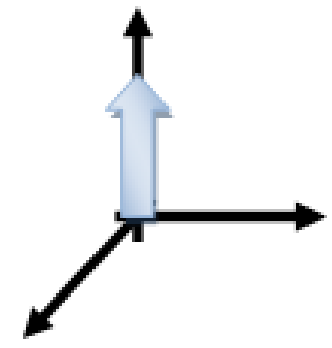

Figure 3. The ICT axis (only)

Scenario 3. An institution decides to get the ISO 9001 entitlement, since this kind of certification can later be used as a promotion for the organization itself. However at the time quality processes are being revised one can see that the quality policy just establishes that the teacher has to have a class plan before entering the classroom, Even though all the academic personnel carries out the activity of planning as established in the policy, such class planers show no proof of ICTs, nor is there evidence of a convenient pedagogy.

It is challenging for schools to abide to a multid isciplinary task in which staff has to demonstrate ICTs ability a long with pedagogy that turns out to be a quality meaningful learning for the day by day more competitive student.

It is important not only review the curriculum separately from educational policies, it is necessary to evaluate them together to increase the value of education. It is important to evaluate them together to give a better meaning of significance about education to the student, and it is important to evaluate them together to increase the quality in educational Mexican scenarios.

\section{Policy Continuity}

One problem is the lack of connection of pedagogy with ICTs and these two with Management, and another is the one which normally accompanies Educational Policies: continuity, for Aranut education has had a more or less establish policy continuity in Mexico, since the last three presidential administrations have tried to follow up the previous one[1]; however there are those who express that discontinuities in political commitment are more common and gradually the reforms start losing its momentum so that change remains in a few schools or regions [2]. It will not be discussed in this paper, if educational policies have to get rid of previous trends, wiping out even s mall details, or the other way around; that is to say to keep it up with the previous trend and then to come up with a few changes where enhancement is always sought. What it is discussed is the implementation of an educational policy.

Education has experienced different changes, for example, not so long ago it was believed that constructivism would work things out, and nowadays it is seen that competencies has to substitute the previous policy, to that matter Dale Schunk exp lains rather than have a unique educational trend, all of them are a complement to one another[3]; in other words competencies approach is not against constructivism nor are these two against meaningful learning or holistic education, so on and so forth, curriculum has to have this multi task fle xibility[4].

Comparable to pedagogy some decision makers should not forget to vary stimuli, it is common to see how technologies in education die without having reached a mature age. Teachers are first trying to become skillful at using slides for a presentation with a computer and a projector and all of a sudden they are asked to produce videos, and soon afterwards to create animations. This constant migration has not given off the best practices in the majority of cases.

\section{Background}

\subsection{The Basic Education and its Policies}

Let us recall the National Modernization Agreement for Basic Education (ANMEB, for its abbreviation in Spanish) as well as the recent reforms to junior high or secondary school; the former stands for a governmental attempt to adhere parental support to children's school performance, among other intentions; and the latter seeks implementation of competencies approach.

After some years of having implemented them,PISA results displays a not very encouraging outcome, neither for students nor for decision makers.

\subsection{Higher Education}

Higher Education services represent a condition to enhance individuals who will become the mid-class and high level staff within the organizations of the different fields of study[5]. Universities, Faculties and Higher Education Institutions represent a paradigmatic issue in Mexican Politics, this kind of organizations has found support from different governmental administrations;[1] nonetheless government does not give money away to all kind of schools, but the other way around, economical support is tight to results, for instance, depending on the number of researchers and their projects, patents, and so on; the budget can be increased or decreased, or is kept the same.

\subsection{The Curriculum}

Higher Education, every now and then experiences the creation of a new career, or else an old one gets to be re-designed, it is known that international organizations such as UNESCO, The World Bank, International Monetary Fund, 
and others dictate to developing countries the way their education should be[6], regarding recent years the educational policy focuses on innovation, and flexibility; [4] and that matter implies the curricula. Unfortunately, at the time that there is an attempt for establishing a new curriculum, there has been little or no change at all, many institutions tend to copy and imitate what others are carrying out[7], so the resulting curriculum is a cover up or a disguise for the lack of work from teachers and mid management positions at schools.

Educational Policies show the need to change, the necessity to have schools become more flexible, innovative and so on; however the question is: How much pedagogy does flexibility imply? What is the link between innovation and ICTs? How does mid-management participate within this process?

\section{Mind Management Trying to Come to Grips}

Mid management of higher education plays the leading part for curricular design, it is an irresponsible role when local authorities just to hand out the law or government regulation to teachers, because the principle of effort integration form holistic education is being avoided, for instance, basic education in Mexico has been decentralized and federal authorities hand over responsibility to the States and they, in turn, pass it out to municipalities; each municipality displays it to a number scholar zones and school sectors, and finally the school principal finds himself in the need to deliver it to teachers as is, see figure 4.

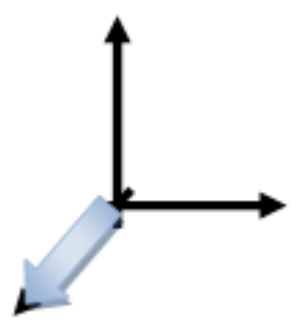

Figure 4. The Management axis

When it was the time for the ANMEB or the Secondary School Educational Reform (RES) to come into being, there is no clear data on how much participation was added up due to the involvement of all the mid management levels,: id est. school principals, schools supervisor, school delegates, local school minis ters, high rank education ministers, so on and so forth. It is not being said that none of the authorities gave a contribution at all, or that their contribution was null; because there have certainly been some results, however those attempts remain somehow isolated and far fro $\mathrm{m}$ being the threshold to a significant change all over the Nation.

There is a saying used by some Mexican that says, "lo que no estáprohibido, estápermitido" (what law has not prohibited, it has been permitted), this scenario may trigger the possibility to avoid some responsibility, in other words when a policy does not specify what is expected from local authorities as well as from the mid management, turns out to be a gap, or like Karl Weick calls it "a loosely coupled systems"[8]. To fasten the loose bolts and nuts it takes more than strength, Juan Manuel Escudero explains that when a curricular project takes place, it starts a task full of tension, trouble and difficulties [9]. Such an event has to be worked out main ly be the mid management.

\subsection{Educational Policy and Curriculum in Higher Education}

The educational policy sometimes gets to be misunderstood and the individual characters of educational systems act out as being in a relay race, it can be pictured that a school principal runs first, then a teacher takes the baton, and this one passes it to someone else, etc. the problem in this hypothetical scenario is not the turn they take, or the strength they have, but the direction they follow; because one can hold the reins in one way and the next one may change the direction, and in the end, after several people have guided the process, it is hard to identify where the curricular gaps started. For example higher education public schools in Mexico and other developing economies have come to realize that English as a Foreign Language is a need for alumni in general; so this language gets to be taught, however the contents of such a subject are not linked to the academic profile within the career and it is seen that the curricular design at universities sometimes includes topics such as booking a room, asking for food in a restaurant, describing a vacation, so on and so forth; nevertheless a very few Mexicans at public universities have had the chance to live this kind of situation, so regarding this example it is conveyed that one part of the curricula trains students for something far from useful.

There are two different projects when curricular design takes place[9], one is the Curricular Project, and the other is the Admin is trative one and both are carried out in a parallel way, the first aspect that a policy has usually omitted is the establishment of contributions on local authorities and mid-management personnel, id est. out of the ' $n$ ' hiera rchical positions the policy rarely expresses what is the input given by each one of them; and also, the regulation might specify that in case of avoiding such responsibility the penalty implied.

\subsection{Educational Policy and Participation}

Once that an Administrative Project comes into being it would be recommendable for it to specify communications flow, as well as a number of tasks, the former feature because everyone should know why the rest of the learning units, subjects, credits and/or activities are either indispensable for the curriculum, necessary for the field of study or complementary to alumni training. The latter trait, because every project has a number of phases or stages and key positions must take the leading role. Problems start as these 
phases take place as Gustavo Rojas describes; Innovation and tradition go in opposite directions[4] tradition, understood as a condition in which people attempt to keep the same scheme rather than take a new role.

\subsection{Educational Policy being Staged}

Policies in Education tend to describe the scenario to reach out, for instance some of the recent policies have established that higher education must allow and enhance creativity, it should also display flexible schemes, it is unavoidable the competencies approach, and the like; regarding the competencies approach Miguel A. Zabalza explains that it is very difficult for a teacher to picture himself in a competencies scenario, because he himself has not clearly staged it, he says that teachers can barely describe what kind of differences there are in a classroom situation with competencies approach and one without it[10]. At this point the policy should tight up the ad ministrative staff and make it clear for everyone what is the scope of his/her contribution.

\subsection{Curricul ar Design being Orchestrated}

A curricular design can be seen as a big orchestra in which all instruments are being played; from the beginning to the end, musicians play and get silence, allowing that other players add up to the master's piece. Regard ing an orchestra there is a person who has written out the music scores, so is the case of the educational policy, there is a government office which has created the policy or reform; nevertheless this educational policy, seen here as a music score paper does not yet establish that, the first part should be played, for example, by an oboe along with five violins, and then the second part has to be performed by piano alone as a solo, then the third part is carried out by forty per cent of the instruments, and so on and so forth.

\subsection{Curricular Lines}

If someone stood up at a university and asked an assorted group of teachers these two questions. How many curricular lines are there in this career where you teach ' $x$ ' learning unit? How does your learning unit interact with other subjects during and after the school term? The answer mightn't be encouraging. It could be found a relatively big group of university professors who do not find themselves as part of a big orchestra, but lost in a sea; it would be similar to a musician who is good at playing the flute but someone who ignores the pace and volume of the other instruments; in other words teachers at universities usually know what they teach, but cannot see the interaction with the others. At this point, it is suitable to make it clear that not all universities staff presents this kind of problem since there are higher education teachers who understand the whole curricular structure and are able to describe classes are linked.

Music, to be presented by an orchestra needs to be rehearsed, however not always is it observed a similar scenario for curricular development, it is like having a unique due date without rehearsals, unfortunately for some universities it can be seen the mistake of dividing the responsibility into smaller tasks allowing little or none feedback fro mone another, giving off an entropy that can be exemplified as it follows. Let us say that there is a university with the same career in different campuses, this university has the need either to create a new career or redesign an existing one; if the process goes independent form beginning to end the only thing in common that campuses will find at the end is discrepancies. In contrast, at the time information flows have been charted, stages for revisions are evaluated from campus to campus in a collaborative way, gaps can be faded. The construction of a curriculum is similar to the construction of a building, the bigger the structure is the greater the problem is just as Clark says that Growth contributes to division[11], nevertheless it is the mid management plan the one responsible for managing communication, evaluate tasks and provide feedback at all times

\section{Conclusions}

Educational policies have attempted to improve educational results; they present the governmental initiative to strengthen either one or various aspects within school. Educational Policies and Curricula tend to avoid the specific course of action throughout particular regions. The biggest challenge of a police is to provide the collaboration schemes, and the continuity between them, A lan Riding once said that Mexicans are successful at individual sports such as boxing or marathon, however they lack the capacity to work in teams, that is the reason why soccer teams are not as successful as box fighters[12], curricular design displays a similar lack of integration, it will not until after that different positions within education establish a suitable atmosphere of collaborative work that policies get the result desired.

\section{ACKNOWLEDGEMENTS}

The authors would like to acknowledge to the Universidad De La Salle Bajío for the support given for realising this work.

\section{REFERENCES}

[1] Aranut, Alberto, and Silvia Giorguli. Los grandes Problemas de México VII. México: El Colegio de México, 2010.

[2] Ferrer, Guillermo. «Las reformas curriculares de Perú, Colombia Chile y Argentina ¿Quién Responde por los Resultados?» Edited by Grade. 2004. http://www.grade.org. pe/asp/brw_pub11.asp?id=627

[3] Schunk, Dale. Learning Theories an Educational Perspective 2nd Edition. Mexico: Prentice-Hall, 1996.

[4] Rojas Bravo, Gustavo. Modelos Universitarios: Los Rumbos 
alternativos de la Universidad y la Innovación. México: Fondo de Cultura Económica, 2005.

[5] Cordera, Rolando, and Alicia Ziccardi. Las Políticas Sociales de México al fin del milenio. Descentralización, Diseño y Gestión. México: Porrua-UNAM, 2000.

[6] Frigerio, Graciela et al. Políticas, instituciones y actores en educación. Buenos Aires: Novedades Educativas, 2000.

[7] Latapi Sarre, Pablo. Un siglo de Educación en México Tomo II. México: Fondo de Cultura Económica, 1998.

[8] Weick, Karl. «Educational Organizations as Loosely Coupled Systems.»Administrative Quarterly vol. 21, March. 1976.
[9] Álvarez Fernández, Manuel, Serafín Antúnez, Juan Manuel Escudero, José Antonio Aroca, and José Ma Barranco. El proyecto Educativo de la Institución Escolar. 2a Edición. Barcelona: GRAÓ, 2002.

[10] Zabalza, Muguel Ángel. Competencias Docentes del Profesorado Universitario. Madrid: Narcea, 2003.

[11] Clark, Burton R. The Higer Education System.Los Angeles: California University Press, 1983.

[12] Riding, Alan. Vecinos Distantes: Un retrato de los Mexicanos. Mexico: Planeta, 1987. 